\title{
Penyelesaian Sengketa Pemilihan Umum di Indonesia
}

\author{
Mhd. Ansori ${ }^{1}$ \\ Fakultas Hukum Universitas Batanghari Jambi
}

\begin{abstract}
Abstrak. Perwujudan demokrasi di Indonesia salah satunya dilakukan Pemilihan Umum, hal ini merupakan suatu kontestasi politik yang tidak jarang menghadirkan sengketa. Terdapat suatu pemahaman umum bahwa proses dan mekanisme penyelesaian sengketa pemilu yang efektif merupakan suatu sine qua nonbagi pemilu yang jujur dan adil.Sebaik-baik sistem penyelenggaraan pemilihan umum dirancang di dalamnya selalu ada kemungkinan terjadi pelanggaran yang dapat mereduksi kualitas pemilihan umum, untuk itu sebaik-baik sistem penyelenggaraan pemilihan umum, di dalamnya senantiasa tersedia mekanisme kelembagaan terpercaya untuk menyelesaikan berbagai jenis keberatan dan sengketa pemilihan umum.Sengketa atau perselisihan dapat dibagi menjadi dua, yaitu: (1) sengketa dalam proses pemilihan umum (khususnya yang terjadi antar-peserta pemilihan umum atau antar kandidat) yang selama ini ditangani panitia pengawas pemilihan umum; dan (2) sengketa atau perselisihan hasil pemilihan umum.Tulisan ini bertujuan untuk mengetahui dan menganalisis penyelesaian sengketa pemilihan umum di Indonesia.Tipepenelitian yang digunakan adalah penelitian yuridis normatif,penelitian ini menggunakan "pendekatan konseptual, pendekatan perundang-undangan, dan pendekatan sejarah.
\end{abstract}

Kata Kunci : Penyelesaian, Sengketa, Pemilihan Umum

Abstract. The realization of democracy in Indonesia is one of which is carried out by general elections, this is a political contestation which often present disputes.There is a general understanding that effective electoral dispute resolution mechanisms and processes are a "sine qua non" for fair and fair elections. As well as the implementation of the general election system is designed in there is alwayas a possibility of violations that can reduce the quality of general elections, for that as well as the implementation of the general election system, within it is always available a trusted istitutional mechanism to resolve various types of general election objections and disputes.Disputes or disputes can be divided into two, that is (1) disputes in the electoral process (especially those that occur between participants in the general election or between candidates) which have been handled by the election supervisory committee and election results disputes or disputes. This paper aims to find out and analyze the dispute resolution of elections in Indonesia.The type of research used is normative juridical research, using conceptual approach, legislation approach, and historical approach.

Keyword : settlement, dispute, general election

\section{PENDAHULUAN}

Perwujudan demokrasi di Indonesia salah satunya dilakukan Pemilihan Umum, hal ini merupakan suatu kontestasi politik yang tidak jarang menghadirkan sengketa. Sebaik-baik sistem penyelenggaraan pemilu dirancang di dalamnya selalu ada kemungkinan terjadi pelanggaran yang dapat mereduksi kualitas pemilu, untuk itu sebaik-baik sistem penyelenggaraan pemilu, di dalamnya senantiasa tersedia mekanisme kelembagaan terpercaya untuk menyelesaikan berbagai jenis keberatan dan sengketa pemilu. ${ }^{2}$ Pelanggaran pemilu dapat terjadi sejak perencanaan, persiapan, tahapan hingga perhitungan suara hasil pemilu. ${ }^{3}$

Pertama, pelaksanaan pemilu di negara kita masih diiringi oleh berbagai sengketa maupun pelanggaran yang dilakukan oleh berbagai pihak. Kedua, lahirnya Undang-Undang Pemilu baru melahirkan perubahan penyelesaian sengketa sehingga perlu dipahami oleh berbagai pihakyang terlibat dalam pemilu. Ketiga, beberapa putusan peradilan dan praktik dalam pemilu ikutmewarnai penyelesaian

\footnotetext{
${ }^{1}$ Mhd.Ansori, Dosen Fakultas Hukum Universitas Batanghari
}

${ }^{2}$ Firdaus, Penyelesaian Sengketa Pemilu sebagai Upaya Memulihkan Kepercayaan dan Memperkuat Legitimasi Pemerintahan Demokrasi, Fiat Justisia Jurnal Ilmu Hukum Vol.8 No.2 Tahun 2014, Fakultas Hukum Universitas Lampung, hal. 209

${ }^{3}$ Firdaus, Penyelesaian Sengketa Pemilu sebagai Upaya Memulihkan Kepercayaan dan Memperkuat Legitimasi Pemerintahan Demokrasi, Fiat Justisia Jurnal Ilmu Hukum Vol.8 No.2 Tahun 2014, Fakultas Hukum Universitas Lampung, hal. 209 
sengketa sehingga perlu diulas.Salah satu hal baru dalam dua kali pemilu terakhir di Indonesia adalah dalam hal disediakannya mekanisme gugatan keberatan terhadap hasil pemilu. ${ }^{4}$

Terkait gugatan keberatan terhadap hasil pemilu menjadi kewenangan lembaga negara yaitu Mahkamah Konstitusi, sebagaimana termuat dalam Undang-Undang Dasar Negara Republik Indonesia Tahun 1945 Pasal 24C ayat (1) yang menentukan bahwa; Mahkamah Konstitusi berwenang mengadili pada tingkat pertama dan terakhir yang putusannya bersifat final untuk menguji Undang-Undang terhadap Undang-Undang Dasar, memutus sengketa kewenangan lembaga negara yang kewenangannya diberikan oleh Undang-Undang Dasar, memutus pembubaran partai politik dan memutus perselisihan tentang hasil pemilihan umum. Hal demikian sesuai dengan pendapat Herma yanti bahwa Mahkamah Konstitusi adalah fungsi peradilan untuk menegakkan hukum dan keadilan, dalam rangka menegakkan supremasi konstitusi. ${ }^{5}$

Berdasarkan ketentuan Pasal 24C ayat (1) UUD 1945, dapat diketahui bahwa: pertama, munculnya keberadaan lembaga negara baru, yaitu Mahkamah Konstitusi (MK) dalam struktur ketatanegaraan Indonesia; kedua, salah satu wewenang MK adalah memutus perselisihan tentang hasil pemilu. Dengan demikian, MK dalam penyelenggaraan pemilu memiliki kedudukan strategis karena kewenangannya mengadili pada tingkat pertama dan terakhir, serta putusannya yang bersifat final, akan memiliki pengaruh besar terhadap hasil akhir pemilu. ${ }^{6}$

Berbagai lembaga mengemukakan standar-standar pemilu demokratis.Salah satunya IDEA yang menyebut 15 unsur, yaitu: (1) structuring the legalframework; (2) the electoral system: (3) boundary delimitation, districting ordefining boundaries of electoral units: (4) the right to vote and to be elected; (5)electoral management bodies; (6) voter registration and voter registers; (7) ballotaccess for political parties and candidates; (8) democratic electoral campaigns; (9)media access and freedom of expression; (10) campaigns finance and expenditure;(11) balloting; (12) votes counting and tabulating; (13) role of the representativesof the parties and candidates; (14) electoral observers; dan (15) compliance andenforcement of electoral law.Berkaitan dengan unsur ke-15 di atas, sesuai standar internasional suatukerangka hukum mestilah:

"... provide that every voter, candidate and political party has the right tolodge a complaint with the competent electoral management bodies (EMB)or court when an infringement of electoral rights is alleged to have occurred.The law must require that the appropriate EMB or court render a promptdecision to avoid aggrieved party losing his/her electoral right. The law mustprovide a right of appeal to an appropriate higher level of EMB or court withauthority to review and exercise final jurisdiction in the matter. The decisionof the court of last resort must be issued promptly."

Dari uraian tulisan diatas maka penulis merumuskan masalah yang terbatas pada "Bagaimanakah penyelesaian sengketa pemilihan umum di Indonesia?"

Dengan tujuan untuk mengetahui dan menganalisa penyelesaian sengketa pemilihan umum di Indonesia.

Teori penyelesaian sengketa pemilu

Teori sistem hukum (legal system theory) juga digunakan untuk menganalisis permasalahan, menurut Lawrence M.Friedman, dikatakannya dalam sistem hukum mengandung 3 (tiga) komponen yaitu struktur hukum (legal structure), subtansi hukum (legal substance) dan budaya hukum (legal culture). ${ }^{8}$

Komponen struktur hukum dalam hal ini mencakup berbagai institusi yang diciptakan oleh sistem hukum dengan berbagai macam fungsinya dalam rangka mendukung bekerjanya sistem hukum tersebut, salah satu institusi tersebut adalah Badan/Panitia Pengawas Pemilu (Bawaslu/Panwas) yang

${ }^{4}$ Ramlan Surbakti dkk, Seri Demokrasi Elektoral Buku 16 Penanganan Sengketa Pemilu, Kemitraan Bagi Pembaruan Tata Pemerintahan, 2011, hal. 1

${ }^{5}$ Herma Yanti, Gagasan constitutional Complaint Sebagai kewenangan Baru Mahkamah Konstitusi dalam Perlindungan Hak Konstitusional, Jurnal Wajah Hukum, Volume 2 Nomor 2 (Oktober 2018), Hal. 186

${ }^{6}$ Ramlan Surbakti dkk, Seri Demokrasi Elektoral Buku 16 Penanganan Sengketa Pemilu, Kemitraan Bagi Pembaruan Tata Pemerintahan, 2011, hal. 1

${ }^{7}$ International IDEA, International Electoral Standards, Guidelines for Reviewing the Legal Framework

of Elections, Stockholm: International Institute for Democracy and Electoral Assistance, 2002, h.

93-94.

${ }^{8}$ Lawrence M.Friedman, The Legal System : A.Social Science Perspektive, Russel Sage Foundation, New York, 1969, hal.16. 
menjalankan fungsinya sebagai struktur hukum kemudian komponen struktur hukum (legal structure) ini relevan untuk membahas permasalahan, yang menekankan pada upaya dalam menyelesaikan sengketa yang terjadi dalam pemilihan kepala daerah dengan substansi hukum meliputi aturan-aturan hukum, norma-norma dan pola perilaku nyata manusia yang berada dalam sistem itu termasuk produk yang dihasilkan oleh orang yang berada di dalam sistem hukum itu, mencakup keputusan-keputusan yang mereka keluarkan atau aturan baru yang mereka susun, sementara budaya hukum yang dimaksud adalah keadaan budaya (culture) masyarakat hukum dalam penyelesaian masalah ini antara lain Bawaslu/Panwas, KPU, DKPP dan Pasangan Calon/Partai Politik pengusung dalam memberi respon terhadap norma atau aturan hukum perundang-undangan terkait penyelesaian sengketa pemilihan. ${ }^{9}$

Menurut Gustav Radbruch dari tiga tujuan hukum (yaitu keadilan, kemanfaatan, dan kepastian hukum), keadilan harus menempati posisi yang pertama dan utama dari pada kepastian dan kemanfaatan. Memanglah demikian bahwa keadilan adalah tujuan hukum yang pertama dan utama, karena hal ini sesuai dengan hakekat atau ontologi hukum itu sendiri. ${ }^{10}$

\section{METODE PENELITIAN}

Tipe penelitian yang digunakan adalah penelitian yuridis normatif,Penelitian ini menggunakan "pendekatan konseptual, pendekatan perundang-undangan, dan pendekatan sejarah"11.

Bahan-bahan hukum yang telah diperoleh, diinventarisasi dan diidentifikasi untuk digunakan sebagai bahan dalam menganalisis pokok permasalahan dalam penelitian ini. Identifikasi bahan hukum baik primer, sekunder, maupun tertier dilakukan secara kritis, logis, dan sistematis, dikumpulkan berdasarkan sistem kartu (card system), "yang memuat sumber yang tepat dari mana catatan itu diambil, informasi atau pendapat yang digunakan, pokok masalah serta kartu yang digunakan adalah kartu kutipan, kartu ulasan, kartu ikhtisar" 12 hal ini dilakukan untuk mempermudah proses pengolahan data hukum tersebut, dengan demikian bahan hukum akan disusun dan digolongkan menurut bentuk, jenis dan tingkatnya. Adapun bahan hukum yang digunakan dalam penelitian ini adalah:

a. Bahan hukum primer terdiri dari peraturan perundang-undangan yang berhubungan dengan masalah yang dibahas seperti:UUD 1945, Undang-Undang, Peraturan Pemerintah, Peraturan Daerah,dan lain-lain.

b. Bahan hukum sekunder yaitu bahan hukum yang dapat memberikan penjelasan mengenai bahan hukum primer, seperti:rancangan undang-undang, hasil-hasil penelitian, hasil karya dari kalangan hukum baik berbentuk buku, jurnal hukum, makalah dan lain-lain.

c. Bahan hukum tertier yakni bahan hukum yang dapat memberikan petunjuk maupun penjelasan terhadap bahan hukum primer dan sekunder.Contohnya: kamus, ensiklopedia, indeks komulatif,dan lain-lain

Kemudian dianalisa dengan cara :

a. Menginterpretasikan semua peraturan perundang-undangan sesuai masalah yang dibahas.

b. Menilai bahan-bahan hukum yang berhubungan dengan masalah yang diteliti.

c. Mengevaluasi peraturan perundang-undangan yang berhubungan dengan masalah yang dibahas.

\section{HASIL DAN PEMBAHASAN}

Sistem penyelenggaraan pemilu yang baik bukan saja karena kesuksesan memungut suara. Cukup banyak model penataan kelembagaan penyelesaian keberatan dan sengketa pemilu yang berkembang dalam praktek negara-negara di dunia, Robert Dahl dan Michael Clegg mengidentikasi masalah-masalah pokok dan aspek yang harus dipertimbangkan dalam membangun sistem pemeriksaan kebertan dan sengketa di antaranya :

a. Kejelasan kompetensi lembaga yang harus menerima, memeriksa, dan menyelesaikan keberatan dan sengketa pemiludari tingkat pertama hingga tingkat banding;

${ }^{9}$ Herdi Munte dkk, Penyelesaian Sengketa Administrasi Pemilihan Kepala Daerah Berdasarkan Undang-Undang Nomor 8 Tahun 2015 Tentang Pemilihan Gubernur,Bupati Dan Walikota, USU Law Journal, Vol.5.No.1 (Januari 2017), hal. 159

${ }^{10}$ Herdi Munte dkk, Penyelesaian Sengketa Administrasi Pemilihan Kepala Daerah Berdasarkan Undang-Undang Nomor 8

Tahun 2015 Tentang Pemilihan Gubernur,Bupati Dan Walikota, USU Law Journal, Vol.5.No.1 (Januari 2017), hal. 160

${ }^{11}$ Bahder Johan Nasution, Metode Penelitian Ilmu Hukum, (Bandung:Mandar Maju,2008), hlm. 92.

${ }^{12}$ Ibid., hal. 106. 
b. Mekanisme dan prosedur mengenai kapan, di mana, bagaimana dan dalam bentuk apa keberatan atau permohonan harus diajukan, termasuk syarat pembuktian, tenggang waktu yang rasional, dan ketat baik pengadu maupun badan yang menangani perkara;

c. Persyartan, format permohonan, dan formulir yang mudah didapatkan;

d. Menentukan pihak-pihak yang dapat mengajukan permohonan keberatan dan sengketa;

e. Prinsip transparansi, meliputi pertimbangan hukum dan bukti-bukti penunjang yang jelas serta putusan yang terpublikasi dengan baik;

f. Diseminasi melalui pendidikan dan pelatihan untuk meningkatkan pemahaman dan pengetahuan masyarakat dalam mengajukan permohonan keberatan dan gugatan guna memulihkan kembali kesalahan yang dapat mereduksi wibawa pemilu;

g. Kejelasan kategori pelanggaran beserta kejelasan jenis dan bentuk sanksi berdasarkan tingkat kesalahan, kelalaian, kesengajaan dan perilaku berulang. ${ }^{13}$

Sengketa atau perselisihan dapat dibagi menjadi dua, yaitu: (1) sengketa dalam proses pemilu (khususnya yang terjadi antar-peserta pemilu atau antar kandidat) yang selama ini ditangani panitia pengawas pemilu; dan (2) sengketa atau perselisihan hasil pemilu. Sesuai ketentuan UUD 1945, UU Pemilu, dan UU MK; wewenang penyelesaian perselisihan hasil pemilu beradadi tangan Mahkamah Konstitusi. Sebenarnya ada lagi sengketa yang ketiga, yang tidak diatur di dalam UU, yakni: (3) sengketa peserta atau calon yang keberatan atas penetapan KPU atau KPUD. Sejumlah masalah terjadi dalam pemilu dan pilkada terjadi sebagai akibat kekurangan aturan main yang perlu diperbaiki pada masa mendatang. Salah satu masalah yang kerap muncul adalah keputusan penyelenggara pemilu mengenai peserta pemilu dan kandidat presiden (serta kandidat kepala daerah). Gagalnya calon peserta pemilu serta bakal kandidat presiden dan kepala daerah akibat keputusan penyelenggara pemilu masih terus terjadi. ${ }^{14}$

Untuk mengetahui permasalahan yang diungkapkan dalam penulisan ini digunakan teori sistem hukum yang didukung oleh teori kepastian hukum dan teori negara hukum "Pancasila". Teori besarnya adalah teori negara hukum yang dikembangkan oleh JJ. Rosseau ${ }^{15}$, dimana prinsipnya apabila dalam pelaksanaan kewenangannya, pemerintah melanggar hak-hak warga negara harus ada pengadilan administrasi yang menyelesaiakannya. Pemikiran ini diperkuat dengan konsep negara hukum Pancasila yang diperkenalkan oleh Mochtar Kusuma Atmaja dimana di dalam masyarakat diperlukan berbagai peraturan yang mengatur segala tindak tanduk manusia sampai sedetail-detailnya demi kelancaran hidup masyarakat dan untuk mencegah hambatan-hambatan atau ketidakadilan. ${ }^{16}$

Teori sistem hukum (legal system theory) juga digunakan untuk menganalisis permasalahan. Menurut Lawrence M.Friedman, dikatakannya dalam sistem hukum mengandung 3 (tiga) komponen yaitu struktur hukum (legal structure), subtansi hukum (legal substance) dan budaya hukum (legal culture). ${ }^{17}$ Komponen struktur hukum dalam hal ini mencakup berbagai institusi yang diciptakan oleh sistem hukum dengan berbagai macam fungsinya dalam rangka mendukung bekerjanya sistem hukum tersebut. Salah satu institusi tersebut adalah Badan/Panitia Pengawas Pemilu (Bawaslu/Panwas) yang menjalankan fungsinya sebagai struktur hukum. Komponen struktur hukum (legal structure) ini relevan untuk membahas permasalahan, yang menekankan pada upaya dalam menyelesaikan sengketa yang terjadi dalam pemilihan kepala daerah.Substansi hukum meliputi aturan-aturan hukum, norma-norma dan pola perilaku nyata manusia yang berada dalam sistem itu termasuk produk yang dihasilkan oleh orang yang berada di dalam sistem hukum itu, mencakup keputusan-keputusan yang mereka keluarkan atau aturan baru yang mereka susun. Sementara budaya hukum yang dimaksud dalam tesis ini adalah keadaan budaya (culture) masyarakat hukum dalam

${ }^{13}$ Firdaus, Penyelesaian Sengketa Pemilu sebagai Upaya Memulihkan Kepercayaan dan Memperkuat Legitimasi Pemerintahan Demokrasi, Fiat Justisia Jurnal Ilmu Hukum Vol.8 No.2 Tahun 2014, Fakultas Hukum Universitas Lampung, hal. 216

${ }^{14}$ Ramlan Surbakti dkk, Seri Demokrasi Elektoral Buku 16 Penanganan Sengketa Pemilu, Kemitraan Bagi Pembaruan Tata Pemerintahan, 2011, hal. 3

${ }^{15}$ Dwi Rezki Sri Astarini, Mediasi Pengadilan : Salah Satu Bentuk Penyelesaian Sengketa Berdasarkan AsasPeradilan Cepat, Sederhana, Biaya Ringan, Alumni, 2013, hal. 16

${ }^{16}$ CFG. Sunaryati, Hartono, Hukum Ekonomi Pembangunan Indonesia, Binacipta, 1988, hal. 20

${ }^{17}$ Lawrence M.Friedman, The Legal System : A.Social Science Perspektive, Russel Sage Foundation, New York,1969, hal.16. 
penyelesaian masalah ini antara lain Bawaslu/Panwas, KPU, DKPP dan Pasangan Calon/Partai Politik pengusung dalam memberi respon terhadap norma atau aturan hukum perundang-undangan terkait penyelesaian sengketa pemilihan.

Teori kepastian hukum dikemukakan oleh Roscoe Pound. ${ }^{18}$ Teori kepastian hukum mengandung 2 (dua) pengertian yaitu pertama, adanya aturan yang bersifat umum membuat individu mengetahui perbuatan apa yang boleh atau tidak boleh dilakukan dan kedua, berupa keamanan hukum bagi individu dari kesewenangan pemerintah karena adanya aturan hukum yang bersifat umum itu individu dapat mengetahui apa saja yang boleh dibenarkan atau dilakukan negara terhadap individu.

Dikaitkan dengan fungsi Bawaslu/Panwaslu dalam penyelesaian sengketa pemilu atau sengketa pemilihan adalah tergambar jelas berfungsi sebagai peradilan semu (adjudikasi) dalam memutuskan sengketa. Dalam konteks peradilan semu (bukan peradilan murni) berlaku prinsip rechtmatigheid dan doelmatigheid. Istilah rechtmatigheid dan doelmatigheid merupakan istilah yang berasal dari ranah hukum administrasi negara.

Berdasarkan Undang-Undang Nomor 7 Tahun 2017 Tentang Pemilihan Umum, ada beberapa hal terkait sengketa proses pemilu, diantaranya :

Pasal 466

sengketa proses pemilu meliputi sengketa yang terjadi antar-peserta pemilu dan sengketa peserta pemilu dengan penyelenggara pemilu sebagai akibat dikeluarkannya keputusan KPU, keputusan KPU provinsi, keputusan KPU kabupaten/kota.

\section{Pasal 470}

Ayat 1 sengketa proses pemilu melalui pengadilan tata usaha negara meliputi sengketa yang timbul dalam bidang tata usaha negara Pemilu antara calon anggota DPR, DPD, DPRD provinsi, DPRD kabupaten/kota, atau partai politik calon Peserta Pemilu, atau bakal pasangan calon dengan KPU, KPU Provinsi, KPU Kabupaten/Kota, sebagai akibat dikeluarkannya keputusan KPU, kepuitusan KPU Provinsi, KPU Kabupaten/Kota.

Mengenai penyelesaian sengketa proses pemilu di Bawaslu, penyelesaian sengketa proses pemilu di Pengadilan Tata Usaha Negara, tata cara penyelesaian sengketa proses pemilu melalui Pengadilan Tata Usaha Negara, Majelis Khusus Tata Usaha Negara Pemilu termuat dalam Pasal 467 sampai dengan Pasal 472 Undang-Undang Nomor 7 Tahun 2017 Tentang Pemilihan Umum.

Perselisihan hasil pemilu meliputi perselisihan antara KPU dan Peserta Pemilu mengenai penetapan perolehan suara hasil Pemilu secara nasional hal ini sebagaimana termuat dalam Pasal 473 Undang-Undang Nomor 7 Tahun 2017 Tentang Pemilihan Umum, kemudian tata cara penyelesaian perselisihan hasil pemilu termuat dalam Pasal 474 dan Pasal 475 Undang-Undang Nomor 7 Tahun 2017 Tentang Pemilihan Umum.

Sengketa yang seringkali disebut sama dengan konflik yang menurut Ali Achmat berpendapat"sengketa adalah pertentangan antara dua belah pihak atau lebih yang berawal dari persepsi yangberbeda tentang suatu kepentingan atau hak milik yang dapat menimbulkan akibat hukum bagikeduanya". 19

Berdasarkan dua pengertian sengketa di atas, dapat diuraikan menjadi beberapa elemen antara lain : 1) adanya dua pihak atau lebih; 2)adanya hubungan atau kepentingan yang sama terhadap objek tertentu; 3)adanya pertentangan dan perbedaan persepsi; dan 4) adanya akibat hukum.

Namun secara sfesifik, defenisi sengketa pemilihan berdasar Peraturan Bawaslu Nomor 8 tahun 2015 tentang tata cara penyelesaian sengketa pemilihan gubernur, bupati dan walikota, pasal 2 ayat 2), mendefenisikan penyelesaian sengketa dilakukan karena adanyasengketa yang timbul karena : perbedaan penafsiran atau suatu ketidakjelasan tertentu mengenai suatu masalah kegiatan dan/atau peristiwa yang berkaitan dengan pelaksanaan Pemilihan sebagaimana diatur dalam ketentuan peraturan perundangundangan; keadaaan dimana terdapat pengakuan yang berbeda dan/atau penolakan penghindaran

\footnotetext{
${ }^{18}$ Peter Mahmud Marzuki, Pengantar Ilmu Hukum, Prenada Media Group 2008, hal. 158

${ }^{19}$ Herdi Munte dkk, Penyelesaian Sengketa Administrasi Pemilihan Kepala Daerah Berdasarkan Undang-Undang Nomor 8 Tahun 2015 Tentang Pemilihan Gubernur,Bupati Dan Walikota, USU Law Journal, Vol.5.No.1 (Januari 2017), hal.160
} 
antarpeserta Pemilihan atau antara peserta pemilihan dengan penyelenggara pemilihan; dan keputusan KPU Provinsi atau keputusan KPU Kabupaten/Kota.

Namun dari kedua defenisi umum dan sfesifik tersebut, tetap ada kesamanaan unsurnya yaitu : adanya dua pihak atau lebih, adanya hubungan dengan masalah atau objek tertentu, adanya pertentangan/pengakuan berbeda/penolakan/penghindaran dan adanya akibat hukum.

Dalam pemahaman yang lama, dasar gugatan dalam perselisihan hasilpemilu cukup terbatas, yaitu adanya kesalahan dalam keputusan mengenaihasil pemilu yang dikeluarkan oleh KPU. Dasar gugatan ini pada akhirnyamenentukan sejauh mana pengadilan akan memutuskan kasus tersebutapakah hanya pembatalan penghitungan dan perintah untuk menghitungulang, atau menyatakan batal suatu hasil pemilu dan perintah dilakukanpemilihan ulang, Pada perkembangannya, MK mengubah pemahaman lama ini karena MK kemudian memberi putusan yang lebih luas, termasuk memberi putusan pemungutan ulang atau penghitungan ulang. Masalah yang menjadi pokok persoalan gugatan juga lebih luas, bukan hanya persoalan kesalahan penghitungan KPU saja, tetapi mencakup berbagai pelanggaran dalam proses,bahkan persyaratan kandidat. $^{20}$

Pemohon keberatan harus mengajukan permohonan kepada Mahkamah Konstitusi dalam jangka waktu "3 kali 24 jam sejak pengumuman oleh KPU tentang penetapan hasil pemilu secara nasional". Permohonan diajukan secara tertulis dalam bahasa Indonesia oleh pemohon atau kuasanya kepada Mahkamah Konstitusi dalam 12 (dua belas) rangkap setelah ditandatangani oleh:

a. Ketua Umum dan Sekretaris Jenderal dari dewan pimpinan pusat atau nama yang sejenisnya dari Partai Politik Peserta Pemilu atau kuasanya.

b. Ketua Umum dan Sekretaris Jenderal dari dewan pimpinan atau nama yang sejenisnya dari partai politik lokal atau kuasanya.

c. Calon anggota DPD peserta Pemilu atau kuasanya.

d. Pasangan Calon Presiden dan Wakil Presiden atau kuasanya.

Luasnya wilayah Indonesia dapat menjadi kendala sendiri dalam memenuhi tenggat waktu "3 kali 24 jam" di atas akan tetapi dengan adanya mekanisme permohonan secara online atau alat lainnya (faksimili) sangat membantu, dalam hal ini permohonan yang diajukan calon anggota DPD dan/atau partai. ${ }^{21}$

Jadi, perselisihan yang diselesaikan oleh Mahkamah Konstitusi adalahperselisihan mengenai penetapan hasil pemilihan umum yang dilakukansecara nasional oleh Komisi Pemilihan Umum yang memengaruhi: terpilihnyacalon anggota Dewan Perwakilan Daerah; penentuan pasangan calon yangmasuk pada putaran kedua Pemilihan Umum Presiden dan Wakil Presidenserta terpilihnya pasangan calon Presiden dan Wakil Presiden, dan perolehankursi partai politik peserta pemilihan umum di suatu daerah pemilihan. ${ }^{22}$

Ada tiga jenis putusan MK untuk perkara perselisihan hasil Pemilu 2004, yaitu: (1) permohonan tidak dapat diterima; (2) permohonan ditolak; dan (3) permohonan dikabulkan. Permohonan dinyatakan tidak diterima adalah permohonan yang gugur di luar substansi, dengan berbagai kemungkinan penyebab, yaitu karena permohonan tidak memenuhi persyaratan administratif; bukan merupakan kewenangan MK; atau karena tidak signifikan pengaruhnya terhadap posisi perolehan kursi yang ada. Permohonan dinyatakan ditolak apabila permohonan memenuhi persyaratan administratif, perkaranya merupakan kewenangan MK, dan pengaruhnya signifikan terhadap posisi perolehan kursi yang ada, namun dalil yang diajukan tidak terbukti. Sedangkan permohonan dinyatakan dikabulkan apabila permohonan yang diajukan memenuhi persyaratan administratif, merupakan kewenangan MK, pengaruhnya signifikan terhadap posisi perolehan kursi yang ada, dan dalil yang diajukan terbukti. ${ }^{23}$ Pada Pemilu 2009, jumlah perkara untuk Perselisihan Hasil Pemilu DPR dan DPRD sebanyak 42 perkara, yakni dari seluruh partai politik peserta pemilu dengan kasus sebanyak 627 kasus. Dari jumlah ini 68 dikabulkan, 398 ditolak,107 tidak diterima, dan 27 ditarik

\footnotetext{
${ }^{20}$ Ramlan Surbakti dkk, Seri Demokrasi Elektoral Buku 16 Penanganan Sengketa Pemilu, Kemitraan Bagi Pembaruan Tata Pemerintahan, 2011, hal. 6

${ }^{21}$ Ramlan Surbakti dkk, Seri Demokrasi Elektoral Buku 16 Penanganan Sengketa Pemilu, Kemitraan Bagi Pembaruan Tata Pemerintahan, 2011, hal. 9

${ }^{22}$ Ramlan Surbakti dkk, Seri Demokrasi Elektoral Buku 16 Penanganan Sengketa Pemilu, Kemitraan Bagi Pembaruan Tata Pemerintahan, 2011, hal. 18

${ }^{23}$ Ramlan Surbakti dkk, Seri Demokrasi Elektoral Buku 16 Penanganan Sengketa Pemilu, Kemitraan Bagi Pembaruan Tata Pemerintahan, 2011, hal. 19
} 
kembali. Juga terdapat enam putusan perhitungan suara ulang dan dua pemungutan suara ulang. Untuk Pemilu Presiden dan Wakil Presiden terdapat dua kasus, sedangkan Pemilu Anggota DPD terdapat 28 kasus. $^{24}$

Terdapat suatu pemahaman umum bahwa proses dan mekanisme penyelesaian sengketa pemilu yang efektif (effective electoral dispute resolution mechanisms and processes) merupakan suatu sine qua non bagi pemilu yang jujur dan adil, Ada tiga isu fundamental dalam penyelesaian sengketa pemilu, yaitu: (1) Validitas hasil, dan dengan demikian hak untuk menguji atau menggugat hasil pemilu; (2) Tindakan administratif dari para penyeneggara pemilu untuk memperbaiki atau menyelesaikan suatu masalah, yang dipersoalkan oleh para pencari keadilan yang hak-hak pemilu dilanggar; dan (3) Tuntutan pidana bagi mereka yang melakukan tindak pidana pada proses pemilu. ${ }^{25}$

\section{SIMPULAN}

Penyelesaian sengketa pemilihan umum di Indonesia dapat diselesaikan oleh Badan Pengawas Pemilu, Peradilan Tata Usaha Negara dan Mahkamah Konstitusi, bila terjadi sengketa proses pemilihan umum dapat diselesaikan Badan Pengawas Pemilu dan Peradilan Tata Usaha Negara, lain halnya dengan sengketa hasil pemilihan umum dapat diselesaikan Mahkamah Konstitusi.

\section{DAFTAR PUSTAKA}

\section{Buku}

Bahder Johan Nasution, Metode Penelitian Ilmu Hukum, (Bandung:Mandar Maju,2008), hlm. 92.

CFG. Sunaryati, Hartono, Hukum Ekonomi Pembangunan Indonesia, Binacipta, 1988.

Dwi Rezki Sri Astarini, Mediasi Pengadilan : Salah Satu Bentuk Penyelesaian Sengketa Berdasarkan AsasPeradilan Cepat, Sederhana, Biaya Ringan, Alumni, 2013.

Lawrence M.Friedman, The Legal System : A.Social Science Perspektive, Russel Sage Foundation, New York, 1969.

Peter Mahmud Marzuki, Pengantar Ilmu Hukum, Prenada Media Group 2008.

Ramlan Surbakti dkk, Seri Demokrasi Elektoral Buku 16 Penanganan Sengketa Pemilu, Kemitraan Bagi Pembaruan Tata Pemerintahan, 2011.

\section{Jurnal}

Herdi Munte dkk, Penyelesaian Sengketa Administrasi Pemilihan Kepala Daerah Berdasarkan UndangUndang Nomor 8 Tahun 2015 Tentang Pemilihan Gubernur,Bupati Dan Walikota, USU Law Journal, Vol.5.No.1 (Januari 2017).

Herma Yanti, Gagasan constitutional Complaint Sebagai kewenangan Baru Mahkamah Konstitusi dalam Perlindungan Hak Konstitusional, Jurnal Wajah Hukum, Volume 2 Nomor 2 (Oktober 2018)

Firdaus, Penyelesaian Sengketa Pemilu sebagai Upaya Memulihkan Kepercayaan dan Memperkuat Legitimasi Pemerintahan Demokrasi, Fiat Justisia Jurnal Ilmu Hukum Vol.8 No.2 Tahun 2014, Fakultas Hukum Universitas Lampung.

International IDEA, International Electoral Standards, Guidelines for Reviewing the Legal Frameworkof Elections, Stockholm: International Institute for Democracy and Electoral Assistance, 2002.

\section{Peraturan Perundang-Undangan}

Undang-Undang Dasar Negara Republik Indonesia Tahun 1945

Undang- Undang Nomor 4 Tahun 2014 Tentang Penetapan Peraturan Pemerintah Pengganti UndangUndang Nomor 1 Tahun 2013 Tentang Perubahan Kedua atas Undang-Undang Nomor 24 Tahun 2003

Tentang Mahkamah Konstitusi Menjadi Undang-Undang.

Undang-Undang Nomor 7 Tahun 2017 Tentang Pemilihan Umum.

\footnotetext{
${ }^{24}$ Ramlan Surbakti dkk, Seri Demokrasi Elektoral Buku 16 Penanganan Sengketa Pemilu, Kemitraan Bagi Pembaruan Tata Pemerintahan, 2011, hal. 20

${ }^{25}$ Ramlan Surbakti dkk, Seri Demokrasi Elektoral Buku 16 Penanganan Sengketa Pemilu, Kemitraan Bagi Pembaruan Tata Pemerintahan, 2011, hal. 21
} 